Controversies in Obstetrics and Gynecology

University of Iowa Ob/Gyn Postgraduate Conference

October 28, 2011

Hotel Vetro, Iowa City, IA 52240

\title{
Obesity and assisted reproduction
}

\author{
E. Haran Duran, $\mathrm{MD}^{1}$
}

Excess body weight impacts fertility during both natural and assisted reproduction (ART) cycles. In men, the immediate effect is hypoandrogenism through decreased testosterone levels and an increase in peripheral aromatization of androgens to estrogen, although this does not seem to cause significant change in conventional semen parameters. ${ }^{1}$ In women, the impact seems to be through various pathways, by both animal and human studies. Insulin resistance (IR) typically accompanies obesity, leading to anovulation and hyperandrogenism. Although ovulation can be achieved via ART, oocyte quality is typically poor in these women due to IR, hyperandrogenism and perhaps the underlying inflammatory milieu associated with obesity. ${ }^{2,3}$ Obese woman's endocrinologic environment may potentially lead to unfavorable endometrial changes that may participate in the increased miscarriage rate, in addition to the impact of poor oocyte quality. Exposure to such an environment even during early embryogenesis stage may lead to neonatal as well as life-long consequences in offspring of these women. ${ }^{4,5}$ Among those are both intrauterine growth restriction (IUGR) and macrosomia, early development of metabolic syndrome, insulin resistance, hypertension, and atherosclerotic heart disease. Clinical studies indicate lower likelihood of both clinical and ongoing pregnancy, as well as live birth in obese women. ${ }^{6,7}$ They also indicate reduced number of oocytes retrieved with ART, despite higher doses of gonadotropins used. ${ }^{8}$ Various problems complicate the pregnancy of these women, among which are increased risk of preeclampsia, gestational diabetes, and cesarean section. ${ }^{6}$ The impact of obesity on endometrium is somewhat debatable, since these associations seem to be lost when donated oocytes are used, ${ }^{7}$ although conflicting findings exist. ${ }^{9}$ Further studies are warranted not only to optimize ART outcome in this patient population, but also to prevent consequences in the children of obese women during newborn period as well as the rest of their lives.

\section{References}

1. MacDonald AA, Herbison GP, Showell $M$, Farquhar CM. The impact of body mass index on semen parameters and reproductive hormones in human males: a systematic review with meta-analysis. Hum Reprod Update. 2010 MayJun;16(3):293-311. Epub 2009 Nov 4.

${ }^{1}$ Department of Obstetrics and Gynecology, The University of lowa, lowa City, IA, 52240

Please cite this paper as: Duran, EH. Obesity and assisted reproduction. Proc Obstet Gynecol. 2011 November;2(2):Article 8 [ 2 p.]. Available from: http://ir.uiowa.edu/pog/. Free full text article.

Corresponding author: E. Hakan Duran, Department of Obstetrics and Gynecology, University of lowa, 31322 PFP, 200 Hawkins Drive, lowa City, IA, 52242. Telephone (319)356-4119, hakan-duran@uiowa.edu

This is an Open Access article distributed under the terms of the Creative Commons Attribution 3.0 Unported License (http://creativecommons.org/licenses/by/3.0), which permits unrestricted use, distribution, and reproduction in any medium, provided the original work is properly cited. 
2. Cardozo E, Pavone ME, HirshfeldCytron JE. Metabolic syndrome and oocyte quality. Trends Endocrinol Metab. 2011 Mar;22(3):103-9. Epub 2011 Feb 1.

3. La Vignera S, Condorelli R, Bellanca S, La Rosa B, Mousaví A, Busà B, Vicari LO, Vicari E. Obesity is associated with a higher level of proinflammatory cytokines in follicular fluid of women undergoing medically assisted procreation (PMA) programs. Eur Rev Med Pharmacol Sci. 2011 Mar;15(3):267-73.

4. Wyman A, Pinto AB, Sheridan $R$, Moley $\mathrm{KH}$. One-cell zygote transfer from diabetic to nondiabetic mouse results in congenital malformations and growth retardation in offspring. Endocrinology. 2008 Feb;149(2):466-9. Epub 2007 Nov 26.

5. Rogers LK, Velten M. Maternal inflammation, growth retardation, and preterm birth: insights into adult cardiovascular disease. Life Sci. 2011 Sep 26;89(13-14):417-21.

6. Dokras A, Baredziak L, Blaine J, Syrop C, VanVoorhis BJ, Sparks A. Obstetric outcomes after in vitro fertilization in obese and morbidly obese women. Obstet Gynecol. 2006 Jul;108(1):61-9.

7. Luke B, Brown MB, Stern JE, Missmer SA, Fujimoto VY, Leach R; SART Writing Group. Female obesity adversely affects assisted reproductive technology (ART) pregnancy and live birth rates. Hum Reprod. 2011 Jan;26(1):245-52. Epub 2010 Nov 11.

8. Maheshwari A, Stofberg L, Bhattacharya S. Effect of overweight and obesity on assisted reproductive technology--a systematic review. Hum Reprod Update. 2007 SepOct:13(5):433-44. Epub 2007 Jun 21.
9. Bellver J, Melo MA, Bosch E, Serra V, Remohí J, Pellicer A. Obesity and poor reproductive outcome: the potential role of the endometrium. Fertil Steril. 2007 Aug;88(2):446-51. Epub 2007 Apr 6. 